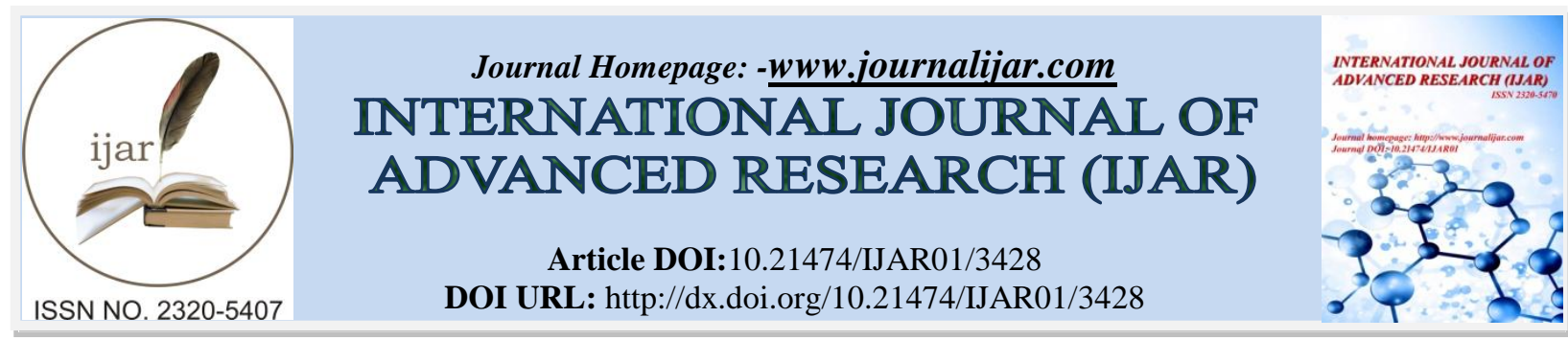

RESEARCH ARTICLE

\title{
CARDIAC TOXICITY AFTER ACUTE YELLOW PHOSPOROUS INGESTION: CASE REPORT.
}

\section{Dr. Ch. Manojkumar MD ${ }^{1}$, Dr. K. S. KeerthiVyas MD² and Dr. Y. Sai Krishna MD².}

1. Associate Professor, Dept of General Medicine, Dr. Pinnamaneni Siddhartha Institute Of Medical Sciences And Research Foundation ,Chinaoutpalli ,Krishna District, Andhra Pradesh, India.

2. Senior Residents, Dept of General Medicine, Siddhartha Medical College ,Vijayawada, Krishna District, Andhra Pradesh, India.

\section{Manuscript Info}

Manuscript History

Received: 12 December 2016

Final Accepted: 16 January 2017

Published: February 2017

Key words:-

Yellow phosphorous arrhythmias, myocardial infarction, hepatic failure.

\section{Abstract}

Yellow phosphorus is an inorganic substance used in fire crackers, fertilizers, and as rodenticide. It has very strong garlicky odor and the toxic dose ranges from $15-100 \mathrm{mg}$. Therefore, in a $70 \mathrm{~kg}$ adult the dose would be approximately $0.2-1.4 \mathrm{mg} / \mathrm{kg}{ }^{[1]}$. The fatality rate has previously been reported to be between $10-50 \%{ }^{[2]}$. The present study report a case of acute yellow phosphorous due to intentional ingestion causing fulminant hepatic failure with cardiovascular involvement of atrial fibriilation and acute inferolateral myocardial infarction. Thereafter, we evaluate the challenges in appropriate management of the case.

Copy Right, IJAR, 2017,. All rights reserved.

\section{Introdction:-}

Elemental phosphorus exists in two forms - red and yellow. Red phosphorus is nonvolatile and unabsorbable, and therefore nontoxic when ingested. Yellow phosphorus (also referred to as white phosphorus),themost readily available source is rodenticide as powders containing 2 to $5 \%$ of compound. ${ }^{(3)}$

Yellow phosphorous is a severe local and systemic toxin causing damage to gastrointestinal, hepatic, cardiovascular, and renal systems.Acute cardiovascular collapse accounted for majority of the deaths. Wedescribe here a case of acute yellow phosphorus poisoning that led to fulminant hepatic failure and developed acute myocardial infarction with atrial fibrillation.

The heart is one of many organs affected by phosphorus, and several electrocardiographic abnormalities have been reported $^{(4,5)}$.However, changes diagnostic of or consistent with myocardial infarction have not been described in previous studies. In the present study we treated a patient with acute yellow phosphorus poisoning whose electrocardiogram disclosed changes interpreted as evidence of acute infarction of the infero-lateral wall of the left ventricle.Eventually, the patient recovered with conservative management with resolution of the abnormal electrocardiographic pattern within few weeks.

\section{Case Report:-}

A 60-year-old man was brought to the hospital with an alleged history of consumption with suicidal intent of an unknown quantity of rodenticide paste (Ratol, containing 3\% yellow phosphorus). He was taken to the local hospital minutes after ingestion and gastric lavage was done. After 2 days he was brought to the emergency due to persistent 
vomiting and jaundice. There was no history of lethargy, altered sensorium, or convulsions. There was no history of abdominal pain, breathlessness, or oliguria.

On admission, the patient was conscious, known diabetic since 2 months and afebrile with blood pressure as 100/60 $\mathrm{mm} \mathrm{Hg}$ and vitals being stable. Mild pallor and icterus was present, but no edema was seen. The liver was palpable $2 \mathrm{~cm}$ below the costal margin, soft, and with rounded margins. Other systems were essentially normal.

Results of the investigations done on the day of admission and subsequently are shown inTable 1. Blood smear for malarial parasites and viral markers were negative. Chest X-ray done was normal and abdominal sonography showed mild hepatomegaly.

On the second day of hospital stay, he was noticed to be lethargic and drowzy. A diagnosis of West Haven classification of Grade2 hepatic encephalopathy was made and the patient was given intravenous (IV) fluids with $10 \%$ dextrose, IV cefotaxime vitamin $\mathrm{K}$ andpantocid. He was also started on oral lactulose. Intake and output was strictly monitored and blood glucose was measured six-hourly.

Despite initiation of antihepatic failure therapy, he progressed to coagulopathy on day 2 of admission with prolonged PT and aPTT and was administered 4 units of fresh frozen plasma.

Table 1:-Lab Investigations.

\begin{tabular}{|c|c|}
\hline LAB PARAMETERS: & \\
\hline HB & $16.4 \mathrm{~g} / \mathrm{dl}$ \\
\hline WBC COUNT & $5400 \mathrm{cells} / \mathrm{mm} 3$ \\
\hline PACKED CELL VOLUME & $49.7 \%$ \\
\hline MCV,MCH,MCHC & Normal limits \\
\hline PLATELETS & $189000 \mathrm{cells} / \mathrm{mm} 3$ \\
\hline SERUM ELECTROLYTES & $\mathrm{Na}[138], \mathrm{K}[3.6], \mathrm{CL}[98], \mathrm{Ca}[8.3]$ \\
\hline BLOOD UREA NITROGEN & $22.18 \mathrm{mg} / \mathrm{dl}$ \\
\hline SERUM CREATININE & $1 \mathrm{mg} / \mathrm{dl}$ \\
\hline BLOOD GROUPING & $\mathrm{B}$ positive \\
\hline
\end{tabular}

Table 2:- Liver Function Test \& Coagulation Profile:

\begin{tabular}{|c|c|c|c|c|c|c|c|}
\hline \multicolumn{2}{|l|}{ Day1 } & \multicolumn{2}{|l|}{ Day3 } & \multicolumn{2}{|l|}{ Day 5} & \multicolumn{2}{|l|}{ Day10 } \\
\hline \multicolumn{2}{|l|}{ LFT } & \multicolumn{2}{|l|}{ LFT } & \multicolumn{2}{|l|}{ LFT } & \multicolumn{2}{|l|}{ LFT } \\
\hline $\begin{array}{l}\text { Sr.Bilirubin } \\
\text { Total } \\
\text { Direct } \\
\text { Indirect } \\
\end{array}$ & $\begin{array}{l}\mathrm{mg} / \mathrm{dl} \\
15.8 ; \\
13.4 ; \\
2.4 ; \\
\end{array}$ & $\begin{array}{l}\text { Sr.Bilirubin } \\
\text { Total } \\
\text { Direct } \\
\text { Indirect } \\
\end{array}$ & $\begin{array}{l}\mathrm{mg} / \mathrm{dl} \\
16.07 ; \\
12.21 \\
3.86\end{array}$ & $\begin{array}{l}\text { Sr.Bilirubin } \\
\text { Total } \\
\text { Direct } \\
\text { Indirect } \\
\end{array}$ & $\begin{array}{l}\mathrm{mg} / \mathrm{dl} \\
12.6 ; \\
8.7 ; \\
3.9 ; \\
\end{array}$ & $\begin{array}{l}\text { Sr.Bilirubin } \\
\text { Total } \\
\text { Direct } \\
\text { Indirect } \\
\end{array}$ & $\begin{array}{l}\mathrm{mg} / \mathrm{dl} \\
10.6 ; \\
6.7 \\
3.9 \\
\end{array}$ \\
\hline SGOT & $\begin{array}{l}860 \\
\mathrm{U} / \mathrm{L}\end{array}$ & SGOT & $194 \mathrm{U} / \mathrm{L}$ & SGOT & $\begin{array}{l}101 \\
\mathrm{U} / \mathrm{L}\end{array}$ & SGOT & $\begin{array}{l}101 \\
\mathrm{U} / \mathrm{L}\end{array}$ \\
\hline SGPT & $\begin{array}{l}930 \\
\mathrm{U} / \mathrm{L}\end{array}$ & SGPT & $466 \mathrm{U} / \mathrm{L}$ & SGPT & $\begin{array}{l}213 \\
\mathrm{U} / \mathrm{L}\end{array}$ & SGPT & $\begin{array}{l}213 \\
\mathrm{U} / \mathrm{L}\end{array}$ \\
\hline ALP & $\begin{array}{l}123 \\
\mathrm{U} / \mathrm{L}\end{array}$ & ALP & $125 \mathrm{U} / \mathrm{L}$ & ALP & $\begin{array}{l}124 \\
\mathrm{U} / \mathrm{L}\end{array}$ & ALP & $\begin{array}{l}124 \\
\mathrm{U} / \mathrm{L}\end{array}$ \\
\hline $\begin{array}{l}\text { TOTAL } \\
\text { PROTEIN }\end{array}$ & $5.9 \mathrm{~g} / \mathrm{l}$ & $\begin{array}{l}\text { TOTAL } \\
\text { PROTEIN }\end{array}$ & $5.38 \mathrm{~g} / \mathrm{l}$ & $\begin{array}{l}\text { TOTAL } \\
\text { PROTEIN }\end{array}$ & $4.8 \mathrm{~g} / \mathrm{l}$ & $\begin{array}{l}\text { TOTAL } \\
\text { PROTEIN }\end{array}$ & $4.8 \mathrm{~g} / 1$ \\
\hline A/G RATIO & 1.81 & A/G RATIO & 1.26 & A/G RATIO & 1.53 & A/G RATIO & 1.53 \\
\hline \multicolumn{2}{|c|}{$\begin{array}{l}\text { COAGULATION } \\
\text { PROFILE }\end{array}$} & \multicolumn{2}{|c|}{$\begin{array}{l}\text { COAGULATION } \\
\text { PROFILE }\end{array}$} & \multicolumn{2}{|c|}{$\begin{array}{l}\text { COAGULATION } \\
\text { PROFILE }\end{array}$} & \multicolumn{2}{|c|}{$\begin{array}{l}\text { COAGULATION } \\
\text { PROFILE }\end{array}$} \\
\hline $\begin{array}{l}\text { PROTHROBIN } \\
\text { TIME }\end{array}$ & 76.8 & $\begin{array}{l}\text { PROTHROBIN } \\
\text { TIME }\end{array}$ & 22.6 & $\begin{array}{l}\text { PROTHROBIN } \\
\text { TIME }\end{array}$ & 16.3 & $\begin{array}{l}\text { PROTHROBIN } \\
\text { TIME }\end{array}$ & 12.8 \\
\hline CONTROL & 12.6 & CONTROL & 12.5 & CONTROL & 12.5 & CONTROL & 12.6 \\
\hline INR & 6.8 & INR & 1.86 & INR & 1.65 & INR & 1.32 \\
\hline aPTT & - & aPTT & 39.6 & aPTT & - & aPTT & 31.2 \\
\hline CONTROL & - & CONTROL & 30.6 & CONTROL & - & CONTROL & 30.6 \\
\hline
\end{tabular}


Figure 1:- ECG Changes Of Acute Inferolateral MI.

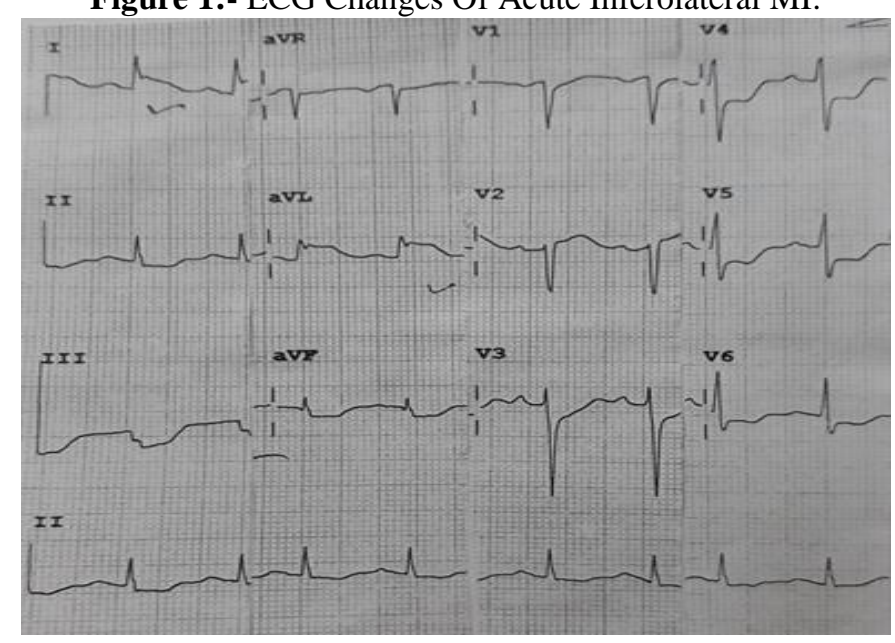

On day 5 of admission he developed chest pain and ECG findings were suggestive of atrial fibrillation with fast ventricular rate along with ST-T CHANGES and broad QRS complex with troponin T positive pointing to acute inferolateralmyocardial infarction. Echocardiographic findings included RWMA of basal inferior and lateral wall mildly hypokinetic with fair LV systolic function with EF $45 \%$. He was stabilized with initial doses of anti platelets, statins and sorbitrate with anti arrhythmic and other supportive measures.

Figure 2:-ECG After 24hrs Resolution Of MI

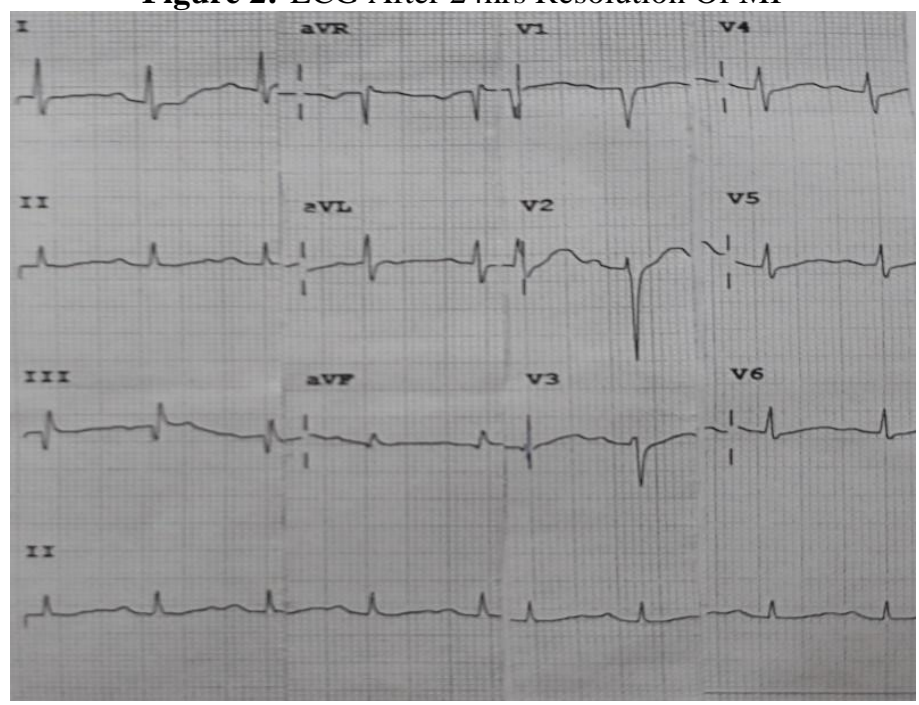

Over 24hrs ECG changes were monitored from evolving phase to resolution phase. He was treated after a plateau period of 10 days, the sensorium started improving, with a simultaneous improvement in his laboratory parameters [Table 2]. Thereafter, he made a partial recovery and was stabilized and discharged after few weeks.

\section{Discussion:-}

Yellow phosphorus is an inorganic substance that can get absorbed through skin, mucus membrane, respiratory and gastrointestinal epithelium. After absorption, the peak level is reached after 2 to 3 hours of toxic oral ingestion. Bile salts are important for absorption of phosphorus. Because of water content and low oxygen tension, phosphorus remains stable in gut for longer period. ${ }^{(3)}$

Fernandez and Cannarez, in their series of 15 patients have reported a mortality of $27 \%$ which confirms that yellow phosphorous is extremely lethal when ingested ${ }^{(6)}$. Phosphorus is a general protoplasmic poison causing cardiac, hepatic, renal, and multi-organ failure. The patient with yellow phosphorus intoxication passes through three stages. The first stage occurs during the first 24 hours in which patient is either asymptomatic or has symptoms of local 
gastrointestinal irritation. The second stage occurs between 24 to 72 hours after ingestion. It is an asymptomatic period where there may be mild elevation of liver enzymes and bilirubin in this stage. The third stage (advanced) occurs after 72 hours until the resolution of symptoms or death.[1]This stage is characterized by multi-organ failure $^{(3,7)}$. Our patient presented to us in stage 3 of intoxication with encephalopathy, acute liver failure, and coagulopathy.

Patients may present with acute hepatic failure, coagulopathy, and deranged liver function, as was witnessed in our patient. Central nervous system effects include changes in mental status like confusion, psychosis, hallucinations, and coma. Some patients may develop acute tubular necrosis and present with acute renal failure. ${ }^{(8)}$

Cardiac toxicity includes hypotension, tachycardia, arrhythmias, and cardiogenic shock ${ }^{(9)}$.Alteration in ECG such as inverted $\mathrm{T}$ waves, changes in QRS complex, tachycardia, arrhythmias and decreased ventricular contractility has been reported ${ }^{(8)}$. In a cross sectional study where 85 patients were studied, dysrhythmias were noted in only two patients, another four showed tachy-bradycardia ${ }^{(10)}$. Damage to myocardium reported in studies included fatty infiltration of the muscle, markedly dilated heart chambers, and necrosis of myocardium ${ }^{(8)}$. Pathological changes in heart were also reported by Tally et al. ${ }^{(9)}$.In our case, the hepatic and cardiac dysfunction was self-limiting and recovered with supportive therapy.

Our patient manifested with arrhythmias and myocardial infarction as a consequence of cardiac toxicity. His cardiac involvement started after 7 days of consumption, thus emphasizing the importance of anticipating this complication as a delayed manifestation. This presentation can complicate the preexistent multi-organ failure.

There is no specific antidote for yellow phosphorus. Treatment is directed at removal of the poison with gastric lavage and supportive therapy. Careful monitoring of hepatic, cardiac and renal function and management of their failure is required. ${ }^{(11)}$

Mortality rates were $23 \%$ for patients who had early symptoms of vomiting or abdominal pain; $73 \%$ for those where the first manifestation of intoxication was restlessness, irritability, drowsiness, stupor, or coma; and $47 \%$ for patients who had a combination of these GI and CNS symptoms initially. ${ }^{(12)}$

\section{Conclusion:-}

Our case report highlights the possibility of late onset persistent cardiac dysfunction as asequelae with yellow phosphorous poisoning necessitating a high index of suspicion for the same. The indiscriminate use of yellow phosphorus in the manufacture should be eliminated. Physicians should therefore be aware of the toxicity and its management.

\section{Limitations:-}

Patients with diabetes are at highrisk for developing cardiovascular disease and associated morbidity and mortality,and this risk increases dramatically with age. In the present study, we are unevident, if the Acute MI is a manifestation of the either the toxicity or a age related event precipitated with the associated stress.

\section{Bibilography:-}

1. Loai Nabil Al Barqouni, Sobhi L Skaik, Nafiz R Abu Shaban, Nabil Barqouni. White phosphorus burn.The Lancet. 2010;376-368.

2. Pande TK, Pandey S. White phosphorous poisoning -explosive encounter. J Assoc Physicians India. 2004;52:249-250.

3. Brent J, Wallace K, Burkhart K. Critical Care Toxicology: Diagnosis and Management of the Critically Poisoned Patient. Philadelphia, PA: Elsievers Saunders;2005:851-861.

4. Raymond.J.Pietras; CharalambosStavrakos; et al Phosporous poisoning simulating acute myocardial infarction Arch Intern Med . 1968;122(5);430-434.

5. Comprehensive medical toxicology book;Dr. Vv Pillay; $2^{\text {nd }}$ edition page95.

6. Fernandez OU, Canizares LL. Acute hepatotoxicity from ingestion of Yellow Phosphorous containing fireworks. J ClinGastroenterol. 1995;21:139-142.

7. Mccarron MM, Gaddis GP, Trotter AT. Acute yellow phosphorous poisoning from pesticide pastes. ClinToxicol. 1981;18:693-712. 
8. Health effects. Toxicology profile for white phosphorous, Agency for Toxic substance and Disease registry: Sep 1997, pp. 51. Available from: http://www.atsdr.cdc.gov/toxprofiles/tp103.pdf. Accessed November 24,2014.

9. Talley RC, Linhart JW, Trevino AJ, Moore L. Acute elemental phosphorus poisoning in man: Cardiovascular toxicity. Am Heart J. 1972;84:139-140.

10. Fabrico Gonzalez-Andrade, Ramiro Lopez-Pulles. White phosphorous poisoning by oral ingestion of fire crackers or little devils: Current experience in Ecuador. Clinical Toxicology. 2011;49:29-33.

11. Ramirez MS, Pacheco J, Gomez N, Fuentes S. Pediatric poisoning by white phosphorous. Survival of potentially lethal dose intake. Arch VenezPueriPediat. 2008;71:140-144.

12. ClinToxicol. 1981 Jun;18(6):693-711.Acute yellow phosphorus poisoning from pesticide pastes.McCarron MM, Gaddis GP, Trotter AT. 